\title{
Dispersal of the Ponto-Caspian amphipod Echinogammarus ischnus: invasion waves from the Pleistocene to the present
}

\author{
MEA Cristescu ${ }^{1}$, JDS Witt ${ }^{1}$, IA Grigorovich ${ }^{2}$, PDN Hebert ${ }^{1}$ and HJ MacIsaac ${ }^{2}$ \\ ${ }^{1}$ Department of Zoology, University of Guelph, Guelph, Ontario, Canada N1G 2W1; ${ }^{2}$ Great Lakes Institute for Environmental Research, \\ University of Windsor, Windsor, Ontario, Canada N9B 3P4
}

\begin{abstract}
The geographical range of the amphipod crustacean Echinogammarus ischnus has expanded over the past century from the Ponto-Caspian region to Western Europe, the Baltic Sea, and the Great Lakes of North America. The present study explores the phylogeographic patterns of this amphipod across its current distribution, based on an examination of nucleotide diversity in the mitochondrial cytochrome $c$ oxidase subunit I (COI) gene. Marked genetic divergence exists among populations of $E$. ischnus from the Black and Caspian Seas, as well as those from the drainage system of the Black Sea. This divergence suggests the prolonged geographic isolation of these native populations,
\end{abstract}

reflecting the limited dispersal capability of $E$. ischnus. By contrast, invading populations are characterized by a lack of genetic variation; a single mitochondrial genotype of Black Sea origin has colonized sites from the Rhine River to North America. The dispersal pattern in $E$. ischnus is very similar to that in the Ponto-Caspian cladoceran Cercopagis pengoi. Despite their contrasting life history strategies, these invading species followed the same route of invasion from the northern Black Sea to the Baltic Sea region, and subsequently to North America.

Heredity (2004) 92, 197-203. doi:10.1038/sj.hdy.6800395

Keywords: phylogeography; mtDNA; COI; Ponto-Caspian; great lakes; nonindigenous species

\section{Introduction}

Most natural communities have experienced an accelerated shift in species turnover in the last century, as a consequence of human-mediated biotic invasions (Williamson, 1996). In North America, for example, a recent analysis has suggested that the current colonization rate of crustaceans originating from Europe is 50000 times that of historic levels (Hebert and Cristescu, 2002). Elucidating both the patterns and rates of natural vs human mediated invasions is an important step in understanding the long-term evolutionary and ecological impacts of these faunal exchanges. Many recent studies have also aimed to predict the likely candidates for invasions and their probable dispersal routes (Ricciardi and Rasmussen, 1998; Kolar and Lodge, 2002; MacIsaac et al, 2002). However, most such efforts suffer from our limited understanding of dispersal patterns for invasive species. Molecular genetic approaches offer a solution to this lack of information, enabling a determination of both the source regions of invasive species and the dispersal corridors employed during their range expansions. Despite this fact, only a few genetic studies have so far examined the source areas of aquatic invaders, their dispersal vectors, or the biological factors that prompt invasions (eg, Spidle et al, 1994; Havel et al, 2000;

Correspondence: MEA Cristescu, Department of Zoology, University of Guelph, Guelph, Ontario, Canada N1G 2W1.

E-mail:mcristes@uoguelph.ca
Cristescu et al, 2001; Berg et al, 2002). No studies have attempted to compare the molecular attributes of different invasive species to determine if patterns of invasion are predictable.

The Ponto-Caspian region, which encompasses the Black, Azov, Caspian, and Aral Seas, has been the most important source of aquatic species that have invaded Western Europe and the North American Great Lakes (Ricciardi and MacIsaac, 2000; Bij de Vaate et al, 2002). Many organisms endemic to the Ponto-Caspian region are currently involved in range expansions, and have colonized Eastern and Western Europe, including the Baltic Sea (Bij de Vaate et al, 2002; Grigorovich et al, 2002). After a first wave of expansion in Europe, several of these invaders including fishes (Proterorhinus marmoratus, Neogobius melanostomus), mussels (Dreissena polymorpha, Dreissena bugensis), and crustaceans (Cercopagis pengoi, Echinogammarus ischnus) have reached the Great Lakes via ballast water discharge, triggering a secondary wave of dispersal in North America (Mills et al, 1993).

The present study employs genetic analyses to reconstruct the dispersal routes employed by the amphipod E. ischnus as it expanded its range beyond the Ponto-Caspian region. This crustacean was first recorded outside its native range in 1928, when it invaded the middle and lower sections of the Vistula River via the Pripet-Bug canal system (Jarocki and Demianowicz, 1931). In 1960, E. ischnus invaded the lower Neman River via the Neman-Pripet Canal (Gasiunas, 1965). The invasion corridor connecting the Dnieper River with the Baltic Sea basin via the Vistula and 
Neman Rivers has been considered the epicenter of its expansion into Europe (Bij de Vaate et al, 2002). During the late 1970s and 80s, E. ischnus was discovered in canals joining the Elbe, Weser, and Ems Rivers, and subsequently in the Rhine-Herne and Wesser-Dattel canals (see Bij de Vaate et al, 2002). Finally, the species dispersed into the Rhine River in 1989 (van den Brink et al, 1993).

E. ischnus was first reported in North America from the Detroit River in 1995 (Witt et al, 1997). However, analyses of archived samples later suggested that the species had invaded western Lake Erie by 1994 and possibly as early as 1993 (van Overdijk et al, 2003). The amphipod subsequently extended its distribution explosively, reaching Lakes Huron, Ontario, and Michigan, as well as the St. Lawrence River, within just 3 years (Witt et al, 1997; Dermott et al, 1998; Nalepa et al, 2001), and Lake Superior no later than 2001 (Grigorovich et al, 2003a). Its invasion of the Great Lakes appears to have occurred largely by natural dispersal, although two 'jumps' into upper Lakes Michigan and Superior were likely associated with the interlake movement of ballast water by commercial ships (Nalepa et al, 2001; Vanderploeg et al, 2002).

Despite its well-documented range extension, little is known about the source localities of these newly established populations, the invasion corridors they exploited, or the number of colonizing events involved. Even less is known about the colonization history of E. ischnus within the Ponto-Caspian area. Most authors consider that its postglacial range encompassed the Caspian Sea (Birshtein and Romanova, 1968), as well as the least saline regions of the Black and Azov Seas (Cărăuşu et al, 1955; Jażdżewski, 1980) and the lower reaches of the Ponto-Caspian watershed (MordukhaiBoltovskoi, 1960). However, it is not known if this distribution was achieved during the late Miocene separation of the Black and Caspian basins, or as a result of subsequent invasion waves triggered by brief periods of contact between these two basins during the Pliocene or Holocene. Behning (1924) and Mordukhai-Boltovskoi (1958, 1960) suggested that E. ischnus extended its range deep into the drainage system of the Black Sea (Danube, Dniester, Southern Bug, Dnieper Rivers), Azov Sea (Don River), and Caspian Sea (Volga River), as a result of natural upstream migrations during the Holocene. However, other authors have suggested the possibility of a relict origin for $E$. ischnus in the large rivers of the Ponto-Caspian watershed, because its distribution is primarily restricted to regions within the late Miocene limits of this basin (eg, Bănărescu, 1991).

In this study, we examine the phylogeographic structure and dispersal patterns of E. ischnus in both the Ponto-Caspian region, and in recently invaded habitats in northern Europe, and the Laurentian Great Lakes using sequence diversity of the mitochondrial cytochrome $c$ oxidase subunit 1 (COI) gene. We also employ a molecular clock to test the hypothesis that Miocene vicariance vs more recent (eg, Holocene) dispersal accounts for its occurrence in both the Black and Caspian Seas. We subsequently contrast patterns of natural vs human-mediated migrations in the dispersal history of this species. Finally, we compare the molecular characteristics of E. ischnus with those of a second crustacean invader from the Ponto-Caspian region, the cladoceran Cercopagis pengoi, to determine if invasion patterns themselves are predictable.

\section{Materials and methods}

\section{Sample collection}

E. ischnus was collected from 20 sites of which 13 were located in the native distribution of the species, including locations along the north-western Black Sea coast and its drainage system, as well as the northern Caspian Sea. The other seven samples were collected from recently established populations in the lower Rhine River and the Great Lakes basin. A second closely allied taxon, Echinogammarus trichiatus, was collected from five localities (Figure 1; Table 1). All individuals were preserved and stored in $95 \%$ ethanol.

\section{DNA extraction, amplification, and sequencing}

Sequence diversity was examined in the mitochondrial COI gene. Total DNA was extracted from two to four individuals from each location, using proteinase $\mathrm{K}$ methods. A 658 base pair (bp) fragment of the COI gene was amplified using the primers LCO1490 and HCO2198 (Folmer et al, 1994). The $50 \mu \mathrm{l}$ PCR reactions contained $1-2 \mu \mathrm{l}$ of DNA template, $5 \mu \mathrm{l}$ of $10 \times$ PCR buffer, $2 \mathrm{mM} \mathrm{MgCl}_{2}, 0.2 \mathrm{mM}$ of each $\mathrm{dNTP}, \quad 0.3 \mu \mathrm{M}$ of each primer, and 1 unit of Taq polymerase. The PCR conditions consisted of $1 \mathrm{~min}$ at $94{ }^{\circ} \mathrm{C}$, followed by five cycles of $60 \mathrm{~s}$ at $94^{\circ} \mathrm{C}, 90 \mathrm{~s}$ at $45^{\circ} \mathrm{C}$, $60 \mathrm{~s}$ at $72^{\circ} \mathrm{C}$; followed by 35 cycles of $60 \mathrm{~s}$ at $94^{\circ} \mathrm{C}, 90 \mathrm{~s}$ at $51^{\circ} \mathrm{C}, 60 \mathrm{~s}$ at $72^{\circ} \mathrm{C}$; followed by $5 \mathrm{~min}$ at $72^{\circ} \mathrm{C}$. PCR products were gel purified using the Qiaex kit (Qiagen Inc) and sequenced in one direction using the ABI 377 automated sequencer using the Big Dye terminator 3 sequencing kit (30 cycles and $55^{\circ} \mathrm{C}$ annealing temperature).

\section{Phylogenetic analyses}

Sequences were aligned by eye using the SeqEd v1.0.3 sequence editor (Applied Biosystems). Pairwise nucleotide sequence distances were calculated in MEGA version 2.1 (Kumar et al, 2001), using the Tamura-Nei distance model, and subsequently used to construct a neighbour-joining phenogram. Pairwise amino-acid sequence distances were calculated with $P$-distances using the invertebrate mitochondrial code. Confidence in the phenetic analysis was assessed with 1000 bootstrap pseudoreplicates. Maximum parsimony heuristic searches were conducted in PAUP 4 b10 on a data set consisting of all unique haplotypes using tree bisection re-connection and random addition of taxa, with the multrees and steepest descent options invoked. Confidence in the parsimony analysis was assessed a priori by estimating the g1 skewness statistic (Hillis and Huelsenbeck, 1992), and a posteriori with 2000 bootstrap pseudoreplicates, with each replicate consisting of three heuristic searches. Standard indices of genetic variation, haplotype diversity $(h)$, and nucleotide diversity $(\pi)$ were calculated for both geographic regions, the PontoCaspian region, and recently invaded habitats using DnaSP 3.53. In order to date the timing of population isolation, we employed the snapping shrimp mitochondrial COI clock of $1.4-2.2 \%$ sequence divergence per million years (Knowlton et al, 1993; Knowlton and Weigt, 1998). 


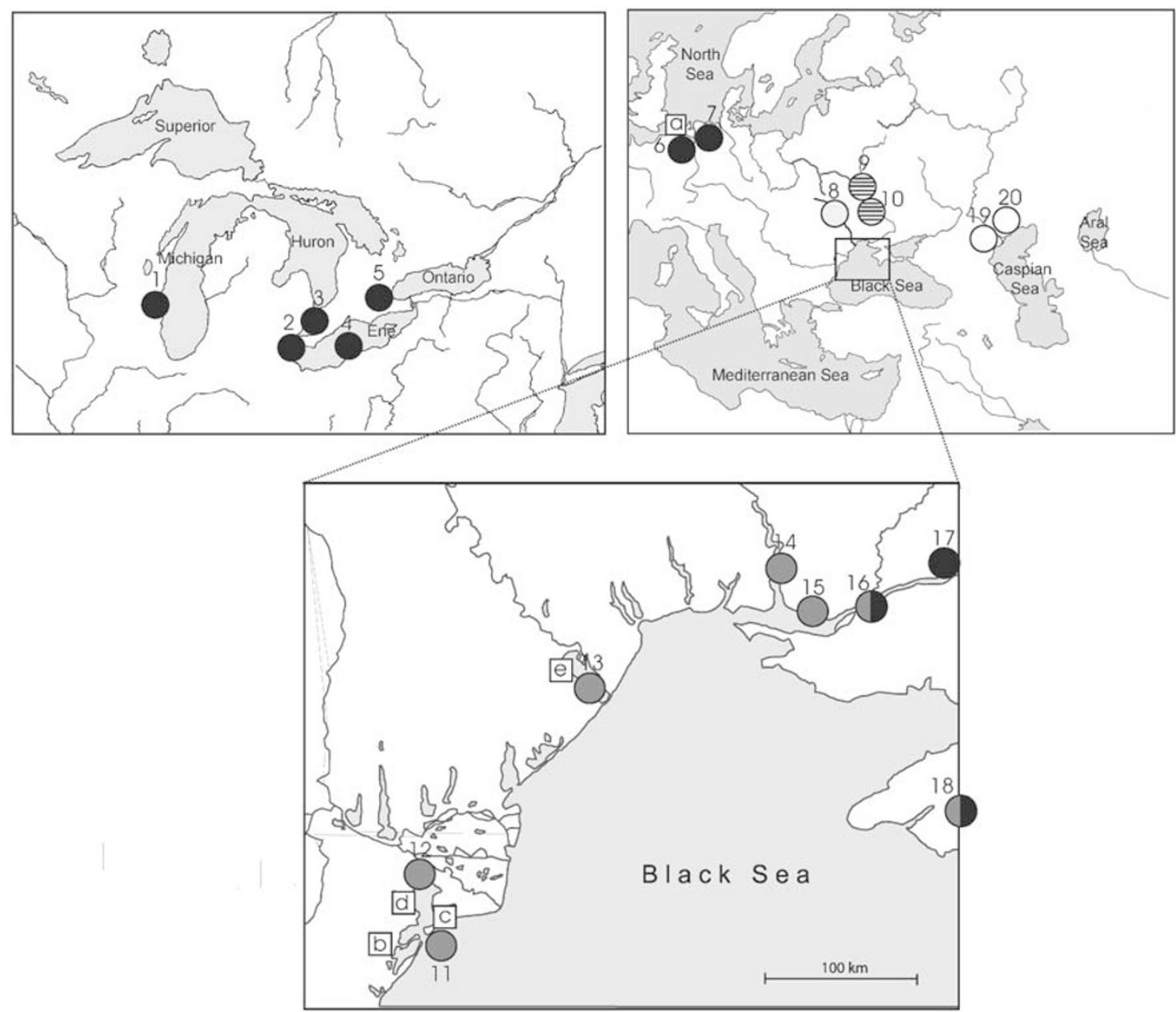

Figure 1 Collection sites for E. ischnus $(\mathbf{O})$ and E. trichiatus $(\square)$. Different symbols indicate cluster membership, as identified by the NJ tree in Figure 2.

\section{Results}

The 642 base pair sequence alignment included 51 sequences derived from $E$. ischnus and 10 sequences from the outgroup taxon E. trichiatus. The alignment was unambiguous, as there were no gaps or nonsense codons among the 61 sequences. All sequences obtained in this study have been submitted to GenBank (accession numbers: AY326115-AY326126).

Among the 61 sequences, 160 nucleotide sites were variable, involving 145 synonymous and 15 nonsynonymous substitutions, while 151 sites were informative using cladistic criteria. The mean base frequencies among the sequences were $34.9 \% \mathrm{~T}, 20.7 \% \mathrm{C}$, $26.6 \% \mathrm{~A}$, and $17.8 \%$ G. Haplotype diversity was significantly higher in populations of $E$. ischnus from its native habitats than in newly invaded habitats. For example, 11 haplotypes $(h=0.89)$ were found in the Ponto-Caspian region, but only one haplotype $(h=0.00)$ was detected in the River Rhine basin and in North America.

The phenetic analysis recovered five phylogenetic clusters showing sequence divergences that ranged from a low of $0.29 \%$ to a maximum of $7.15 \%$ (Table 2 ). Two closely related groups were found in the estuaries and inlets of the Black Sea, while the other three clusters were restricted to the middle Dniester River, the middle Dnieper River, and the Caspian Sea, respectively (Figures 1 and 2). The sole haplotype from newly colonized habitats was also present in populations from the northern Black Sea region, specifically the lower Dnieper River and Simferopol Reservoir. Populations of E. trichiatus showed limited genetic diversity, with only two closely related haplotypes detected.

The maximum parsimony analysis recovered 50 equally parsimonious trees 179 steps long (consistency index $=0.927$, retention index $=0.940)$. The $g_{1}$ skewness statistic was significant $\left(g_{1}=-3.40, \quad g_{1 \text { crit }}=-0.20\right.$, $P=0.01)$, indicating nonrandomized signal in the data set. The parsimony analysis was concordant with the phenetic analysis, and recovered the same haplotype affiliations (Figure 3).

Based on the calibration for snapping shrimp (Knowlton et al, 1993; Knowlton and Weigt, 1998), the Black and Caspian Sea populations of E. ischnus diverged approximately 2.2-3.4 million years (myr) ago, while population divergences within the Black Sea drainage system took place about 1.8-2.8 myr ago. By comparison, the two Echinogammarus species (E. ischnus, E. trichiatus) diverged some 10-16 myr ago. 
Table 1 Sampling sites and collection dates for populations of Echinogammarus ( $\mathrm{N}$ - native habitat; I - recently invaded habitat)

\begin{tabular}{|c|c|c|c|c|c|}
\hline Location & Habitat & Site code & No. of individuals sequenced & Site & Collection date \\
\hline \multicolumn{6}{|l|}{ E. trichiatus } \\
\hline Lower Rhine River & I & a & 2 & Niewe Merwed River & April 02 \\
\hline Danube River Delta & $\mathrm{N}$ & $\mathrm{b}$ & 2 & Sinoie Lake, Istria & June 99 \\
\hline Danube River Delta & $\mathrm{N}$ & c & 2 & Leahova Mica Lake & Aug 01 \\
\hline Danube River Delta & $\mathrm{N}$ & d & 2 & Razim Lake, Agighiol & Aug 99 \\
\hline Dniester Liman & $\mathrm{N}$ & e & 2 & Krasnaya Kosa & Aug 01 \\
\hline \multicolumn{6}{|l|}{ E. ischnus } \\
\hline Lake Michigan & I & 1 & 2 & near Muskegon Lake & Sept 01 \\
\hline Detroit River & I & 2 & 3 & Windsor, Ontario & Feb 99 \\
\hline Lake St. Clair & I & 3 & 2 & Windsor, Ontario & Aug 01 \\
\hline Lake Erie & I & 4 & 3 & Middle Sister Isle & Aug 01 \\
\hline Lake Ontario & I & 5 & 4 & Hamilton Harbour & July 01 \\
\hline Lower Rhine River & I & 6 & 2 & Niewe Merwed River & April 02 \\
\hline Lower Rhine River & I & 7 & 2 & Lobith & Sept 99 \\
\hline Middle Dniester River & $\mathrm{N}$ & 8 & 4 & Novodniestrovsk & Sept 01 \\
\hline Kiev Reservoir & $\mathrm{N}$ & 9 & 3 & Kozarovichi & Sept 00 \\
\hline Irpen River & $\mathrm{N}$ & 10 & 2 & Kozarovichi & Feb 99 \\
\hline Danube River Delta & $\mathrm{N}$ & 11 & 2 & Leahova Mica Lake & Aug 01 \\
\hline Danube River Delta & $\mathrm{N}$ & 12 & 3 & Razim Lake, Agighiol & Aug 99 \\
\hline Dniester Liman & $\mathrm{N}$ & 13 & 3 & Belgorod-Dniestrovskii & Sept 01 \\
\hline Bug Liman & $\mathrm{N}$ & 14 & 3 & Varvarovka & Sept 01 \\
\hline Dnieper Liman & $\mathrm{N}$ & 15 & 2 & Stanislav & Aug 99 \\
\hline Lower Dnieper River & $\mathrm{N}$ & 16 & 3 & Kherson & Aug 01 \\
\hline Kakhovka Reservoir & $\mathrm{N}$ & 17 & 2 & Dam & Aug 99 \\
\hline Simferopol Reservoir & $\mathrm{N}$ & 18 & 2 & Simferopol & Sept 01 \\
\hline Volga River Delta & $\mathrm{N}$ & 19 & 2 & Stream Bystraya & Sept 00 \\
\hline Volga River Delta & $\mathrm{N}$ & 20 & 2 & Priamaya Bolda & Aug 00 \\
\hline
\end{tabular}

Table 2 Mean nucleotide percent divergence $( \pm S E)$ at COI between and within major phylogenetic clusters identified by neighbour-joining analysis (Figure 2; 1 - invaded habitats; 2 - northern Black Sea coast; 3 - Dnieper River; 4 - Dniester River; 5 - North Caspian Sea)

\begin{tabular}{|c|c|c|c|c|c|c|}
\hline Cluster & 1 & 2 & 3 & 4 & 5 & Outgroup \\
\hline 1 & - & $0.29 \pm 0.17$ & $1.65 \pm 0.45$ & $4.05 \pm 0.76$ & $6.20 \pm 0.90$ & $20.41 \pm 1.57$ \\
\hline 2 & $0.29 \pm 0.16$ & $0.22 \pm 0.11$ & $1.61 \pm 0.44$ & $4.23 \pm 0.77$ & $6.15 \pm 0.91$ & $20.67 \pm 1.57$ \\
\hline 3 & $1.68 \pm 0.47$ & $1.64 \pm 0.45$ & $0.28 \pm 0.16$ & $3.77 \pm 0.73$ & $5.95 \pm 0.90$ & $21.28 \pm 1.62$ \\
\hline 4 & $4.25 \pm 0.85$ & $4.44 \pm 0.86$ & $3.95 \pm 0.81$ & - & $6.66 \pm 0.95$ & $21.34 \pm 1.62$ \\
\hline 5 & $6.61 \pm 1.01$ & $6.55 \pm 1.01$ & $6.32 \pm 1.02$ & $7.15 \pm 1.13$ & 0.00 & $20.70 \pm 1.55$ \\
\hline Outgroup & $24.37 \pm 2.34$ & $24.75 \pm 2.36$ & $25.68 \pm 2.44$ & $25.80 \pm 2.45$ & $24.83 \pm 2.31$ & $0.06 \pm 0.05$ \\
\hline
\end{tabular}

The mean uncorrected ( $P$ distance) divergence between clusters is shown above the diagonal. The mean uncorrected divergence within clusters is shown on the diagonal (bold faced). The mean corrected (Tamura-Nei) sequence divergence between clusters is represented below the diagonal.

\section{Discussion}

Ponto-Caspian populations of E. ischnus show marked interbasin genetic divergence and moderate levels of intrapopulation diversity. The clear genetic subdivision between Black and Caspian Sea lineages of this species characterizes the genetic structure of many PontoCaspian crustaceans (Cristescu et al, 2003), and is consistent with the geological history of this region. The two basins have been separated since the beginning of the Pliocene (4-5 myr ago). Although brief periods of contact during the late Pliocene and Pleistocene may have allowed subsequent faunal exchange (Grigorovich et al, 2003b), resident taxa typically exhibit marked genetic differentiation, probably as a joint result of priority effects imposed by first colonists (De Meester et al, 2002) and subsequent local adaptation to varying salinities.
Little genetic divergence was apparent among populations of E. ischnus in isolated brackish water habitats along the Black Sea coast (ie, estuaries, inlets, river deltas). However, substantial genetic differentiation was observed among populations from rivers of the Black Sea catchment area and even between populations from the middle and lower parts of single rivers (Figures 1 and 2). This marked genetic divergence does not support the hypothesis of recent (Holocene) upstream colonization of the drainage systems from the main Black and Caspian basins (Behning, 1924; Mordukhai-Boltovskoi, 1960). Instead, our results suggest a relict origin for populations of $E$. ischnus in the Pontic drainage systems, indicating their role as evolutionary refugia during periods of mass extinction within the Black Sea. In fact, it is likely that glacial melt water washed these relict riverine populations into the Black Sea, leading to its recolonization. 


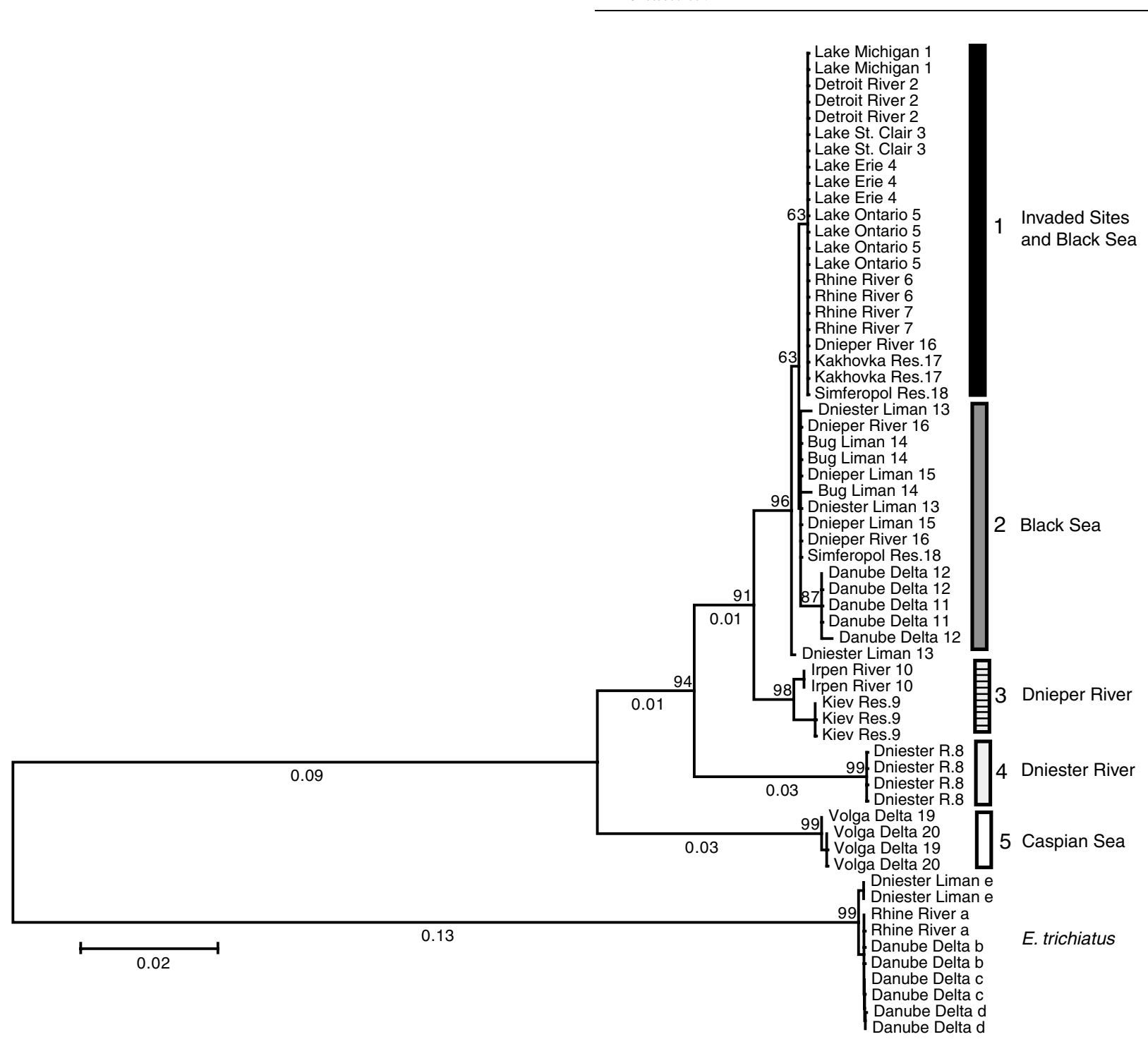

Figure 2 Neighbor-joining (NJ) tree of COI haplotypes from 20 populations of E. ischnus. The tree was rooted using E. trichiatus. Numbers above nodes give the bootstrap percentages (1000 psuedoreplicates), and numbers below branches give the decimal percentage nucleotide distance corrected with the Tamura-Nei model of sequence evolution.

In contrast to the pronounced genetic differentiation within the Ponto-Caspian area, invading populations lacked mitochondrial variation, as only a single genotype was identified from the River Rhine to the Great Lakes (Figure 2). As this genotype was also detected in the northern Black Sea and clustered tightly with other coastal populations from this region, it is likely that range expansion occurred from this area. This result is consistent with potential invasion corridors connecting the Black and Baltic Sea via the Dnieper River and the Pripet-Bug canal system (Jażdżewski and Konopacka, 1990), or connecting the Ukrainian ports at the Black Sea and the North Sea via the Danube and Rhine Rivers and the Main-Danube canal. The Great Lakes may have been invaded indirectly from populations in the Rhine River, or directly via shipping from the Black Sea basin (Ricciardi and MacIsaac, 2000; Cristescu et al, 2001; MacIsaac et al, 2001). However, as the transit time from the Rhine River to the Great Lakes is much shorter than that from the Black Sea and more traffic derives from the former area, it is likely that North American populations of E. ischnus originated from the Rhine (Maclsaac et al, 2002; Colautti et al, 2003).

Cercopagis pengoi is another Ponto-Caspian crustacean with a recent history of invasion into the Baltic Sea and the Great Lakes. A study of mtDNA diversity identified Ukrainian coastal waters on the Black Sea as the source for the Baltic populations of $C$. pengoi, and supported a subsequent transfer from the Baltic Sea to North America (Cristescu et al, 2001). The phylogeographic structure of $E$. ischnus and C. pengoi might have been expected to differ because of their contrasting dispersal abilities (active $v s$ passive) and dissimilar reproductive strategies (sexual vs cyclical parthenogenesis). In fact, populations of E. ischnus did possess higher haplotype diversity ( $h=0.78$ vs $h=0.49$ ), higher nucleotide diversity ( $\pi=0.018$ vs $\pi=0.006)$, and a deeper genetic divergence between Black and Caspian populations (4.8 vs $1.6 \%$ sequence divergence) than those of $C$. pengoi. However, both species followed the same route of invasion from 


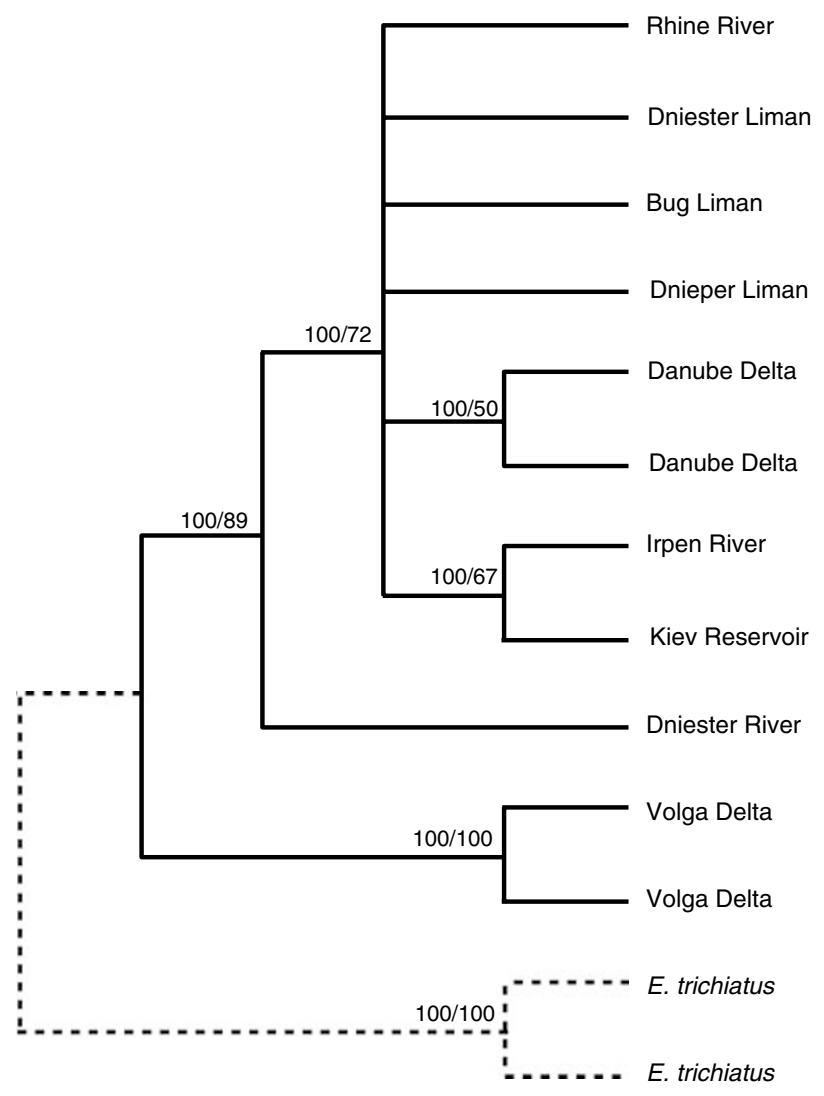

Figure 3 Majority rule consensus cladogram of 50 equally parsimonious trees. Numbers above nodes give the bipartition frequencies among the 50 trees, followed by bootstrap percentages (2000 pseudoreplicates).

the northern Black Sea to the Baltic or North Sea regions and subsequently to North America. Moreover, the paucity of genetic diversity within invading populations of both species suggests either their derivation from a very small number of founders or severe selection following colonization (Lee, 2002). Reduced levels of genetic diversity among recently established populations appear common, as they have been reported in amphipods (Müller et al, 2002a), the Chinese mitten crab (Hanfling et al, 2002), the zebra mussel (Müller et al, 2002b), and the Argentine ant (Tsutsui et al, 2000). This reduction in genetic diversity will place these populations on unique evolutionary trajectories from their parent lineages.

Beyond reconstructing the colonization history of E. ischnus, this study has revealed a strong congruence in invasion patterns between Ponto-Caspian species with different life history attributes and dispersal strategies, suggesting that human-mediated invasion patterns are predictable. This result suggests that the Great Lakes may be more susceptible to Ponto-Caspian invasions than previously thought, since both vagile and poorly dispersing organisms have exploited the same avenues to establish North American populations in similar time frames.

\section{Acknowledgements}

We thank V Serban and GL Mackie for aiding in collections of E. ischnus. This research was supported by Ontario Graduate Scholarships to MEAC, and NSERC grants to PDNH and HJM.

\section{References}

Bănărescu P (1991). Zoogeography of Fresh Waters. Distribution and Dispersal of Freshwater Animals in North America and Eurasia. Verlag Wiesbaden: Aula. Vol. 2.

Behning AL (1924). On the study of bottom life of the Volga river. Monogr Volzhsk Biol Stants Saratov Ob Estestvoispyt 1: 1-398 (in Russian).

Berg DJ, Garton DW, MacIsaac H.J, Panov VE, Telesh IV (2002). Changes in genetic structure of North American Bythotrephes populations following invasion from Lake Ladoga, Russia. Freshwater Biol 47: 275-282.

Bij de Vaate A, Ja K, Ketelaars HAM, Gollasch S, van der Velde G (2002). Geographical patterns in range extension of PontoCaspian macroinvertebrate species in Europe. Can J Fish Aquat Sci 59: 1159-1174.

Birshtein YA, Romanova NN (1968). Order amphipoda. In: Birshtein YA, Vinogradov LG, Kondakov NN, Astakhova MS, Romanova NN (eds) Atlas of Invertebrates of the Caspian Sea. Pishchevaya Promyshlennost: Moscow, Russia. pp 241289 (in Russian).

Cărăuşu S, Dobreanu E, Manolache C (1955). Amphipoda. Brackish and Freshwater Forms. Fauna Republicii Populare Române. Crustacea, Vol. 4, Fasc. 4. Acad. R.P. Române: Bucharest (in Romanian).

Colautti RI, Niimi A, van Overdijk CDA, Mills EL, Holeck K, MacIsaac HJ (2003). Spatial and temporal analysis of shipping vectors to the Great Lakes. In: Ruiz GM, Carlton JT, Mack RN (eds) Invasion Pathways: Analysis of Invasion Patterns and Pathway Management. Island Press: Washington, DC. 227-246.

Cristescu MEA, Hebert PDN, Onciu TM (2003). Phylogeography of Ponto-Caspian crustaceans: a benthic-planktonic comparison. Mol Ecol 12: 985-996.

Cristescu MEA, Hebert PDN, Witt JDS, MacIsaac HJ, Grigorovich IA (2001). An invasion history for Cercopagis pengoi based on mitochondrial gene sequences. Limnol Oceanogr 46: 224-229.

De Meester L, Gomez A, Okamura B, Schwenk K (2002). The monopolization hypothesis and the dispersal-gene flow paradox in aquatic organisms. Acta Oecol 23: 121-135.

Dermott R, Witt JDS, Um YM, Gonzalez M (1998). Distribution of the Ponto-Caspian amphipod Echinogammarus ischnus in the Great Lakes and replacement of the native Gammarus fasciatus. J Great Lakes Res 24: 442-452.

Folmer O, Black M, Hoeh W, Lutz R, Vrijenhoek R (1994). DNA primers for amplification of mitochondrial cytochrome $c$ oxidase subunit I from diverse metazoan invertebrates. Mol Mar Biol Biotechnol 3: 294-299.

Gasiunas II 1965. On the results of acclimatization of fish forage invertebrates of the Caspian complex in the Lithuanian water bodies. Zool Zhurn 44: 340-343 (in Russian).

Grigorovich IA, MacIsaac HJ, Shadrin NV, Mills EL (2002). Patterns and mechanisms of aquatic invertebrate introductions in the Ponto-Caspian region. Can J Fish Aquat Sci 59: 1159-1174.

Grigorovich IA, Korniushin AV, Gray DK, Duggan IC, Colautti RI, MacIsaac HJ (2003a). Lake Superior: an invasion coldspot? Hydrobiologia 499: 191-210.

Grigorovich IA, Therriault TW, MacIsaac HJ (2003b). History of aquatic invertebrate invasions in the Caspian Sea. Biol Invasions 5: 103-115.

Hanfling B, Carvalho GR, Brandl R (2002). mt-DNA sequences and possible invasion pathways of the Chinese mitten crab. Mar Ecol Prog Ser 238: 307-310.

Havel JE, Colbourne JK, Hebert PDN (2000). Reconstructing the history of intercontinental dispersal in Daphnia lumholtzi by the use of genetic markers. Limnol Oceanogr 45: 1414-1420. 
Hebert PDN, Cristescu MEA (2002). Genetic perspectives on invasions: the case of the Cladocera. Can J Fish Aquat Sci 59: 1229-1234.

Hillis DM, Huelsenbeck JP (1992). Signal, noise and reliability in molecular phylogenetic analyses. J Hered 83: 189-195.

Jarocki J, Demianowicz A (1931). ber das Vorkommen des ponto-kaspischen Amphipoden Chaetogammarus tenellus (G.O. Sars) in der Wisła (Weichsel). Bull Acad Polon Sci Cracovie BII: $513-530$.

Jażdżewski K (1980). Range extensions of some gammaridean species in European inland waters caused by human activity. Crustaceana 6(Suppl): 84-107.

Jażdżewski K, Konopacka A (1990). New, interesting locality of the Ponto-Caspian gammarid Echinogammarus ischnus (Stebbing, 1898) (Crustacea, Amphipoda) in Poland. Przeglad Zoologiczny 34: 101-111.

Knowlton N, Weigt LA 1998. New dates and new rates for divergence across the Isthmus of Panama. Proc Roy Soc Lond B Biol 265: 2257-2263.

Knowlton N, Weigt LA, Solorzano LA, Mills DK, Bermingham E (1993). Divergence in proteins, mitochondrial DNA, and reproductive compatibility across the Isthmus of Panama. Science 260: 1629-1631.

Kolar CS, Lodge DM (2002). Ecological predictions and risk assessment for alien fishes in North America. Science 298: 1233-1236.

Kumar S, Tamura K, Jakobsen IB, Nei M (2001). MEGA2: Molecular Evolutionary Genetics Analysis Software. Arizona State University: Tempe, AZ.

Lee CE (2002). Evolutionary genetics of invasive species. Trends Ecol Evol 17: 386-391.

MacIsaac HJ, Grigorovich IA, Ricciardi A. (2001). Reassessment of species invasion concepts: the Great Lakes basin as a model. Biol Invasions 3: 405-416.

MacIsaac HJ, Robbins TC, Lewis MA (2002). Modeling ships' ballast water as invasion threats to the Great Lakes. Can J Fish Aquat Sci 59: 1245-1256.

Mills EL, Leach JH, Carlton JT, Secor CL (1993). Exotic species in the Great Lakes: a history of biotic crises and anthropogenic introductions. I Great Lakes Res 19: 1-54.

Mordukhai-Boltovskoi FD (1958). Process of the distribution of the Caspian fauna during modern epoch. In : Problems of Terrestrial Zoogeography. Izdatelstvo L'vovskogo universiteta: Lvov, The Ukr. SSR. pp 173-182 (in Russian).
Mordukhai-Boltovskoi FD (1960). Caspian Fauna in the Azov and Black Sea Basins, Izdatelstvo Akad. Nauk SSSR: Moscow, Leningrad, The Russ. SFSR (in Russian).

Müller JC, Hidde D, Seitz A (2002b). Canal construction destroys the barrier between major European invasion lineages of the zebra mussel. Proc Roy Soc Lond B Biol 269: 1139-1142.

Müller JC, Schramm S, Seitz A (2002a). Genetic and morphological differentiation of Dikerogammarus invaders and their invasion history in Central Europe. Freshwater Biol 47: 2039-2047.

Nalepa TF, Schloesser DW, Pothoven SA, Hondorp DW, Fanslow DL, Tuchman ML et al (2001). First finding of the amphipod Echinogammarus ischnus and the mussel Dreissena bugensis in Lake Michigan. I Great Lakes Res 27: 384-391.

Ricciardi A, MacIsaac HJ (2000). Recent mass invasion of the North American Great Lakes by Ponto-Caspian species. Trends Ecol Evol 15: 62-65.

Ricciardi A, Rasmussen JB (1998). Predicting the identity and impact of future biological invaders: a priority for aquatic resource management. Can J Fish Aquat Sci 55: 1759-1765.

Spidle AP, Marsden JE, May B (1994). Identification of the Great Lakes quagga mussel as Dreissena bugensis from the Dnieper River, Ukraine, on the basis of allozyme variation. Can J Fish Aquat Sci 51: 1485-1489.

Tsutsui A, Suarez AV, Holway DA, Case TJ (2000). Reduced genetic variation and the success of an invasive species. Proc Natl Acad Sci USA 97: 5948-5953.

van den Brink FW, Paffer BG, Oesterbroek FM, Van der Velde G (1993). Immigration of Echinogammarus ischnus (Stebbing, 1906) (Crustacea, Amphipoda) into the Netherlands via the lower Rhine. Bull Zool Mus Univ Amsterdam 13: 167-170.

Vanderploeg HA, Nalepa TF, Jude DJ, Mills EL, Holeck KT, Liebig JR et al (2002). Dispersal and emerging ecological impacts of Ponto-Caspian species in the Laurentian Great Lakes. Can J Fish Aquat Sci 59: 1209-1228.

van Overdijk CDA, Grigorovich IA, Mabee T, Ray WJ, Ciborowski JJH, MacIsaac HJ (2003). Microhabitat selection by the invasive amphipods Echinogammarus ischnus and native Gammarus fasciatus in laboratory and field experiments in Lake Erie. Freshwater Biol 48: 567-578.

Williamson M (1996). Biological Invasions. Chapman \& Hall: London.

Witt JDS, Hebert PDN, Morton WB (1997). Echinogammarus ischnus: another crustacean invader in the Laurentian Great Lakes basin. Can J Fish Aquat Sci 54: 264-268. 